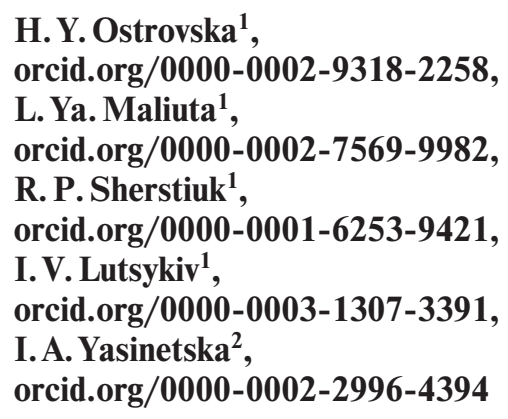

1 - Ternopil Ivan Puluj National Technical University, Ternopil, Ukraine, e-mail: h.ostrovska@gmail.com 2 -State Agrarian and Engineering University in Podilia, Kamianets-Podilskyi, Ukraine

\title{
DEVELOPMENT OF INTELLECTUAL POTENTIAL AT SYSTEMATIC PARADIGM OF KNOWLEDGE MANAGEMENT
}

Purpose. To deepen the methodological foundations and produce recommendations on building the integrated system of knowledge management as a tool of intellectual potential of the industrial enterprise development based on the principles of quality management to achieve the main strategic goal.

Methodology. The methodological basis of knowledge management includes: the theory of the knowledge economy, entrepreneurship, institutionalism, microeconomic theory of knowledge management, the theory of the transformation of knowledge, acquiring new knowledge, the concept of a learning organization, the concept of "triple helix". The basis of the methodology application is system analysis as a scientific method of research on knowledge management organizations functions.

Findings. Theoretical and applied generalization was carried regarding the formation of the concept of industrial enterprise knowledge management in conditions of knowledge-based economy. A new understanding was proposed of the essence of the categories of "knowledge management of industrial enterprises" and "knowledge management system of industrial enterprises". The introduction of knowledge management system was justified that provides for improvement of the knowledge accumulation and integration processes in the field of enterprise activity, knowledge sharing between employees and key stakeholders. Recommendations are developed to improve the knowledge management processes at industrial enterprises, and mechanisms are proposed for their practical implementation.

Originality. The methodology of enterprise management as a dynamic system based on knowledge management was improved. A concept of holistic knowledge management system development and methodical support of its effective use were developed. The suggested integrative model of the enterprise knowledge management system in the mainstream approach process reflects practical aspects of knowledge management concept and is based on the principles of quality management with the purpose of transforming the enterprise into a self-learning organization. The implementation of this concept gives the possibility to create a viable, effective control system for each company that ensures permanent performance of the formation and implementation of learning processes across all business units and in all forms.

Practical value. The proposed development and recommendations of the authors can be used in the context of improving the intellectual potential management efficiency growth to increase economic added value due to generating the organizational knowledge.

Keywords: intellectual potential, knowledge management, the knowledge management system, industrial enterprise, human resources, corporative culture, information infrastructure

Introduction. Knowledge management is a complex and multifaceted process that involves intra-office and external communication and covers all stages of business entities functioning as a complex economic system. In these circumstances, the knowledge management in terms of domestic industrial enterprises is not a luxury but a vital necessity. In operation, they have an urgent need for new management technologies and tools regarding the production implementation, conservation and efficient use of intellectual resources for sustainable development in the conditions of transformational economy. However, to achieve these goals, most enterprises have to reduce the deficit of required knowledge through the generation, detection, diffusion and compensate for lack of competence to enhance competitive advantage. According to this fact, the main task of management in new conditions is to ensure the effective organization of work and increase "intellectual" workers - the "brain" productivity, and in the future - the organization that learns creation. It is an undisputed fact that the leadership of the Ukrainian industrial enterprises is a General idea about the concept of knowledge management and, accordingly, knowledge management resources, and effective methods for using intellectual potential as a daily practice are not taken into account at all. And this is the evidence that the

(C) Ostrovska H.Y., Maliuta L. Ya., Sherstiuk R. P., Lutsykiv I. V., Yasinetska I. A., 2020 individual energy and potential of the individual do not work in economic development [1]. Given the above, the relevance of research is connected with the following: with the purpose of innovative development of an enterprise, a purposeful system of knowledge management is suggested, which, first, would ensure the possibility of transformation of intellectual resources into new products and services; secondly, it would create conditions for the generation of new knowledge and its implementation with the aim of increasing the products (services) added value; thirdly, it would increase the level of knowledge and creative potential of the personnel as a resource, allowing rapid adaptation to the transformational economy conditions.

Literature review. The main impetus for the development of knowledge management theory was based on economic, philosophical and social studies in the second half of the twentieth century dedicated to the phenomenon of knowledge and its role in society. Scientific publications in this field were started by K. Wiig [2]. At the beginning of the $21^{\text {st }}$ century the economic component of knowledge management is reflected in research studies by Ukrainian scientists. The methodological aspects of knowledge management concept have become extensively studied [3], S. Illyashenko examines the areas of marketing and management knowledge in the system of innovative development [4]; N. Smolinska covers aspects of modern enterprises' knowledge management system formation [5], in this context, Y. Sytnyk [6] the direction of staff actualization 
is specified; A. Nalyvayko, O. Grebeshkova and others [7] examine the modern paradigm of strategic knowledge management. The scientific world has been enriched by contemporary models of knowledge management that are proposed. I. Nonaka and H.Takeuchi, G. Stonehouse, A. Slivotskyy and D. Morson, P. Senge, M. Earl, and others. But the problems of knowledge management system formation in line with the process approach with the purpose of development and efficient use of the industrial enterprise's intellectual potential remains controversial.

Methods. In the process of research there were used quantitative and qualitative methods of collecting and analyzing data and information; methods of analytical, situational analysis and synthesis, methods of comparative analysis and methods of management decisions, generalization of scientific experience of modern theoretical research studies, systematic and comprehensive approach.

Purpose. Based on the above, the aim of the study is to deepen the methodological foundations and to develop recommendations on formation of knowledge management integrated system as a tool of development of industrial enterprises' intellectual potential, based on the principles of quality management to achieve the main strategic goal.

Results. Essentially, the classical paradigm of knowledge management reflects the differentiation and segmentation of the learning processes, organizational and work activities. The areas of knowledge management at the enterprise include [5]: knowledge generation; self-organization as basis of the enterprise flexibility; formation of favorable socio-psychological climate in the enterprise; using of knowledge owned by the company with the aim of formulating concepts of operations, development and application of innovative technologies, creation of innovative products and services, problem solving.

In our opinion, industrial enterprises' knowledge management is the concept of strategic management focused on the development and effective use of intellectual potential, based on management methods and new informational technologies to increase or create values of the enterprise and ensure fundamentally new competitive advantages.

Panorama of scientific research studies allows us to testify that the management system of a new type formation - a system of knowledge management can be the key to the success of the domestic industrial enterprises in a difficult competitive environment. The purpose of this system is to balance public needs (market requirements), humanitarian development of workers and specific tasks for the development and effective use of the enterprise's intellectual potential. We should note that, according to the research, top managers of companies, among which $32 \%$ have introduced, while $22 \%$ are working upon a system of knowledge management, stated that the implementation of this system requires significant modifications; there is an urgent problem with the distribution of knowledge at the enterprise [8].

According to these trends, we offer general approaches to building a system of industrial enterprises' knowledge management.

1. Knowledge is information, the gained experience and competence that ensures the enterprise's successful targeted economic activities and development.

2. Knowledge is an organic part of the corporate culture, because it represents a micro model of various processes in which information is presented in a concentrated form, and adapted.

3 . The competition for customers leads to the individualization of demand and consumption. It usually requires the manufacturer to customize products and services. Knowledge is also rapidly "getting individualized", which leads to a sharp increase in implicit knowledge. As a result, we observe cardinal transformation of the labor market: instead of the market "workers" it becomes a market of "smart goals", which are capable of producing new knowledge.

4. Knowledge management is the factors of production and management, which includes two stages: at the first - the key role is played by the processes of collection, processing and transmission of information, every employee gets access to its repositories (global and corporate); at the second (it can be called "creative cognition") employees of the company, taking into account the accumulated experience create new knowledge.

5. Knowledge as a resource is the object of accounting, monitoring, accumulation, storage and periodic updating.

6. In the framework of the "economics of quality" the intellectual component turns the products into the "bundle" of knowledge, so it is inextricably linked to a knowledge based on economy.

7. Knowledge is an integral indicator that reflects corporate intellectual potential.

8. Knowledge objectified in various forms: a stand-alone product; the subject of final consumption; production resource that is used in the manufacture of products; a means of establishing a relationship with the consumer; support resource for management decisions; team consolidation resource and others.

Strategic objectives of knowledge management are determined depending on the positioning in the value chain of the level of innovativeness in manufacturing knowledge products. Summing up the experience in the context of diverse organizational configurations of knowledge management, we should agree with the statement that the key purposes of establishing this system are the following: increasing efficiency of using all available enterprise resources; professional growth of our employees; improving customer service; increasing the innovation development level of production; improving efficiency of using the intellectual potential; reduction of losses from intellectual assets which are not fully utilized; the growth of operating efficiency of industrial enterprises.

It is an undisputed fact that the domestic industrial enterprises knowledge management level does not conform to international standards. Basing on the study of market requirements to product quality, we can conclude that the compliance of the series of ISO quality standards to Western and (in the current economic conditions) domestic enterprises, is often a condition of doing effective business. So important is the integration of the quality management system and enterprise knowledge. The enterprise knowledge management model system we have developed is based on the process approach and reflects a practical approach to the concept of knowledge management, and to improve indicators of activity of the enterprise, it is based on the principles of quality management [10].

1. Achieving sustainable results. The enterprise top-managers are obliged to offer key tools for achieving the goals, mission and vision which will continue to affect the needs of stakeholders.

2. Creating value for customers. The business entity should focus on the client, make every effort to identify measure and address their needs, attract their customers in the processes of the enterprise knowledge management and provide the highest value.

3. Leadership, based on the vision and inspiration of employees: top management must have competencies which allow it to inspire employees, to stimulate their creativity and dedication that is a key to the successful functioning of the industrial enterprise.

4. Process management. Enterprise management should be based on structured and coordinated process to implement the strategy of the enterprise.

5. The staff's pursuit of success. This principle is based on developing a balance between the implementation of business strategy and the needs and desires of the workers.

6. Creativity and innovation - fruitful collaboration with key partners and stakeholders must develop into fostering intellectual and innovative development of the enterprise.

7. Level of partnership. This principle indicates that cooperation with partners in the context of developing new solutions in the field of innovation should not be narrowed only to the integration of participants in the supply chain. 
8. Social and economic responsibility. The innovative enterprise must be guided by ethical principles and values, as well as high standards of organizational behavior and strive for economic, social and environmental stability.

Thus, the formation of a system of knowledge management of modern industrial enterprises implies the existence of such key determinants: human resources (staff, their creative and professional potential), processes (algorithms, storage, sorting, processing, dissemination, exchange and storage of knowledge); organizational structure, which is able to transform individual experiences into products and services that promote and support knowledge sharing; information infrastructure and technology (it is assumed that the following hardware and software would fully satisfy the needs of the management system of enterprise knowledge); corporate culture (culture of individual employees and enterprises in general). Only on condition of close interaction of these elements, the successful functioning of this system can be ensured.
In the knowledge management system, considerable attention is paid to ensuring the processes of their integration. The main functions of knowledge integrators as knowledge professionals are shown in Table 1.

Knowledge accumulation and transfer model construction at different levels of the enterprise management organizational structure is given in Table 2.

The results allow saying that each of certain knowledge levels performs an independent role, carries out its own goals and interacts with each other, thus creating a coherent system. In this way, the organizational structure of the enterprise must comply with the decision of the operational and management challenges, professional roles distribution among the participants of knowledge creating process, the nature of the relationships between them. In addition, such an organization must establish a process of tacit knowledge mobilizing for use in production and feedback between the structures that produce and commercialize knowledge. At the same time, the organizational structure should establish institutional mecha-

Table 1

The main functions of knowledge integrators

\begin{tabular}{|l|l|}
\hline \multicolumn{1}{|c|}{ Function } & \multicolumn{1}{c|}{ Contents } \\
\hline $\begin{array}{l}\text { Accumulation of } \\
\text { knowledge }\end{array}$ & $\begin{array}{l}\text { Objective (resource) accumulation of knowledge is as follows: personalized knowledge is combined with codified } \\
\text { knowledge. As a consequence, accumulation of knowledge as an economic resource is observed. Subjective } \\
\text { accumulation occurs by dissemination of knowledge between participants of the economic process }\end{array}$ \\
\hline $\begin{array}{l}\text { Assurance of intellectual } \\
\text { effect }\end{array}$ & $\begin{array}{l}\text { In modern conditions intellectual resources are considered as priorities. As a result, the intellectual effect is } \\
\text { considered to be the main component of the cumulative scale effect, that is the impact of knowledge in the process } \\
\text { of its accumulation and use by the integrator }\end{array}$ \\
\hline $\begin{array}{l}\text { Commercialization of } \\
\text { knowledge }\end{array}$ & $\begin{array}{l}\text { Market recognition of knowledge achievement and the possibility of obtaining economic benefits from the creation } \\
\text { and use; integration of specialized knowledge into goods and services }\end{array}$ \\
\hline $\begin{array}{l}\text { Providing of transaction } \\
\text { costs savings in the } \\
\text { knowledge integration } \\
\text { process }\end{array}$ & $\begin{array}{l}\text { Measuring and minimizing the costs associated with the transaction, the object of which is information and } \\
\text { knowledge. In modern conditions, a high level of these costs is associated with the quantitative growth of } \\
\text { transactions at the knowledge resources markets, and is also caused by difficulties and peculiarities declaration of } \\
\text { ownership of their different types }\end{array}$ \\
\hline $\begin{array}{l}\text { Knowledge } \\
\text { management }\end{array}$ & $\begin{array}{l}\text { Enterprise knowledge management includes the following subsystems: a) management of intellectual workforce } \\
\text { who are carriers of knowledge; b) the management of intellectual capital, which can be defined as capitalized } \\
\text { knowledge that ensures the growth of the market value; c) the knowledge chain management at the enterprise; d) } \\
\text { providing intellectual security management }\end{array}$ \\
\hline
\end{tabular}

Model of knowledge accumulation and transfer

\begin{tabular}{|c|c|c|c|}
\hline $\begin{array}{c}\text { Level of } \\
\text { knowledge }\end{array}$ & $\begin{array}{l}\text { Methods of knowledge accumulation } \\
\text { and transfer }\end{array}$ & Goals & Efficiency diagnostics objectives \\
\hline $\begin{array}{l}\text { Organizational } \\
\text { level }\end{array}$ & $\begin{array}{l}\text { - value, vision, mission } \\
\text { - philosophy } \\
\text { - corporate publications, magazines } \\
\text { - } \text { organizational structure } \\
\text { - corporate reports (financial and social) }\end{array}$ & $\begin{array}{l}\text { Formation of common values, working } \\
\text { principles and behavior that are } \\
\text { perceived and understood by all } \\
\text { employees }\end{array}$ & $\begin{array}{l}\text { - the survey } \\
\text { - analysis of market trends } \\
\text { - comparison with the best samples } \\
\text { - external research and analysis } \\
\text { - audit }\end{array}$ \\
\hline $\begin{array}{l}\text { Functional } \\
\text { level }\end{array}$ & $\begin{array}{l}\text { - policies and procedures system } \\
\text { - electronic resources } \\
\text { - key indicators } \\
\text { - resources of knowledge (library, training } \\
\text { system, electronic media, and others) }\end{array}$ & $\begin{array}{l}\text { Unit tasks definition, the formation of } \\
\text { common goals that are shared by the } \\
\text { community, the work purpose } \\
\text { explanation, } \\
\text { Assurance of business processes } \\
\text { efficiency }\end{array}$ & $\begin{array}{l}\text { - brainstorm } \\
\text { - focus groups } \\
\text { - optimization of business processes } \\
\text { - analysis of key performance indicators } \\
\text { - evaluation of work of employees }\end{array}$ \\
\hline Team level & $\begin{array}{l}\text { - workplace training } \\
\text { - feedback } \\
\text { - experience } \\
\text { - history } \\
\text { - team mission }\end{array}$ & $\begin{array}{l}\text { Confirmation of rules within the team } \\
\text { Knowledge transfer from a contractor } \\
\text { to a contractor, providing of } \\
\text { interoperability }\end{array}$ & $\begin{array}{l}\text { - a system of training in the workplace } \\
\text { - expertise } \\
\text { - analysis of the performance of the team }\end{array}$ \\
\hline $\begin{array}{l}\text { Individual } \\
\text { level }\end{array}$ & $\begin{array}{l}\text { - personal experience } \\
\text { - best practices sharing } \\
\text { - individual knowledge } \\
\text { - personal values } \\
\text { - knowledge transfer skills }\end{array}$ & $\begin{array}{l}\text { Prioritization } \\
\text { The transfer of knowledge and } \\
\text { experience } \\
\text { Information technologies }\end{array}$ & $\begin{array}{l}\text { - interview } \\
\text { - conversations } \\
\text { - observation } \\
\text { - analysis of results of operations } \\
\text { - feedback }\end{array}$ \\
\hline
\end{tabular}


nisms for individual knowledge transformation to the collective knowledge. In the system of knowledge management such an organizational node can be a kind of Knowledge Center, which ensures the formation of organizational knowledge basis, is responsible for the preservation, synthesis, indexing, retrieving and transferring knowledge from an industry, functional practices, project teams and research laboratories.

A key component of knowledge management at industrial enterprises is an information infrastructure. The organization of developed information infrastructure requires constant monitoring and updating of implemented information technologies, the definition of criteria for their success (or failure), corresponding training of the staff, conversion of business processes of the enterprise. We should note that the information revolution has created unlimited possibilities for knowledge generation. In these circumstances, the main trend of information technologies (IT) development is moving from formalized algorithmic systems to systems which are able to take and combine knowledge. In the framework of knowledge management, information technologies perform functions such as: computing - data analysis; communication - relationship between the knowledge process participants at the enterprise level; saving codification and archiving of accumulated knowledge; transferring - knowledge transfer through internal and external communicational channels; transformational - uncodified knowledge formalizing; searching - relevant types of information and knowledge identification; filtering - sorting of knowledge according to established criteria; spreading - diffusion of knowledge; defending - unique knowledge of the enterprise protection. The list of such technologies is given in Table 3.

Analytical applications and business analytics tools are focused on working with structured data (1-3); they are the IT foundation of successful management. However, the most perceptible information is in an unstructured form. Its part in the structure of all corporate information reaches $80 \%$. Therefore, to build a multifunctional knowledge management system, it is important to work with unstructured information $(4,5)$.

The knowledge management vector provides working with active forms of the enterprise knowledge preservation (Table 4), which is characterized not only by the preservation, but also the transfer of knowledge in an active form (when solving a specific task) and their enrichment in the process of meeting specific problem-oriented requests, self-study.

Today, for large industrial enterprises there is usually a typical situation: many information systems (with different interfaces); the lack of a common data display formats and flexible mechanisms to search for information. As a result, knowl-

Table 3

Components of the information infrastructure of the enterprise knowledge management system

\begin{tabular}{|l|l|}
\hline $\begin{array}{l}\text { Components of the information } \\
\text { infrastructure }\end{array}$ & \multicolumn{1}{|c|}{ IT systems } \\
\hline $\begin{array}{l}\text { 1. Databases and repositories of } \\
\text { data and knowledge }\end{array}$ & Data Warehouse \\
\hline $\begin{array}{l}\text { 2. Tools of operative analytical } \\
\text { data processing }\end{array}$ & $\begin{array}{l}\text { On-Line Analytical Processing, } \\
\text { OLAP }\end{array}$ \\
\hline $\begin{array}{l}\text { 3. Tools of data and text } \\
\text { extraction }\end{array}$ & Data Mining, Text Mining \\
\hline $\begin{array}{l}\text { 4. Document, content and } \\
\text { e-mail management tools }\end{array}$ & $\begin{array}{l}\text { Document management, } \\
\text { Enterprise content management }\end{array}$ \\
\hline $\begin{array}{l}\text { 5. Tools of external information } \\
\text { flow management }\end{array}$ & $\begin{array}{l}\text { Components of Enterprise } \\
\text { content management }\end{array}$ \\
\hline $\begin{array}{l}\text { 6. Tools for organizing } \\
\text { collaboration }\end{array}$ & Collaboration \\
\hline 7. Decision support tools & Decision support \\
\hline
\end{tabular}

edge management should be focused on the establishment and functioning of enterprise information portal as a single tool of access to the enterprise's internal information. The functionality of a common platform in terms of building knowledge management corporate portal is presented in Table 5 .

At the same time, the enterprise's informational portal should evolve in the following directions: creation of content for use by analysis packages such as a system of support of decisionmaking, a management information system; transformation of the portal into an effective tool, a technological mechanism for the removal, forming, and dissemination of knowledge at the enterprise, which enables the corporate network users to communicate with each other, helps to place information in the system of collective understanding, values and experiences; using curriculum to the specific needs of users, which gives you the opportunity to make the learning process continuous, to convert the portal into the center of the learning experience; turning portal into a base for implementation of the enterprise integration practice information programs that will ensure efficient collection of information (structured and unstructured sources of various types). As a side note, the functioning of such knowledge centers at the enterprise must be the beginning of the of knowledge systems that evolve formation, which corresponds to the concept "organization that learns".

According to experts in the field of informational technology and knowledge management, informational infrastructure is comprehensive and well organized due to the following conditions: providing access to centralized information, and to places of its occurrence; the creation of structures and methods of reusing knowledge; development and continuous improvement of a technique of corporate training in the context of knowledge sharing. Powerful infrastructure (information networks, communications, databases, technology), which was created by most Western companies, became the basis for the management of the intellectual potential and capital of modern enterprises.

Paying attention to the ways of knowledge accumulation and transfer, it becomes clear that a significant proportion of the information nucleus is connected with the cultural aspects of the enterprise. It gives all grounds to assert that without adequately established corporate culture it is impossible to implement an effective knowledge management system. Analyzing the structure of corporate culture, we can distinguish three levels: 1) values of the enterprise; 2) norms, standards and rules; 3) behavior (actions) of workers and managers, while the nucleus of any corporate culture involves the values. They define beliefs that guide the activities of all employees of the company.

Depending on the declared values certain standards and norms are getting set, based on which the recognized values are formalized and become the standard. At the same time, enterprise values are manifested in corresponding behavior of employees and managers, in decisions, which are taken and implemented at all levels of management. For the purposes of corporate culture, the greatest importance will have the approach, in which the value is associated with human needs (personal approach) activity motives. However, at the third level of corporate culture (behavior) an important role is given to the evaluation of value as an economic category (what kind of benefit stakeholders get from adhering to the values of the corporate culture first level). Accordingly, the formation of corporate culture of knowledge should be reflected in values, norms, rules of behavior, employee motivation, communication, leadership style and other elements. Thus, the interaction of the knowledge management processes and corporate culture development is the nature of the causal connection. It must be emphasized that depending on the type of corporate culture, approaches of enterprise knowledge management differ. In the first case, the accent is on the formation of professional communities for the creation of knowledge (practical approach), in the second one - on the actual working processes with knowledge (process approach). At the same time, 
Active forms of knowledge preservation

\begin{tabular}{|c|c|c|c|}
\hline Name & Entity & Advantages & Disadvantages \\
\hline $\begin{array}{l}\text { Cloud Computing } \\
\text { ("cloud } \\
\text { computing") }\end{array}$ & $\begin{array}{l}\text { Accumulation of knowledge in the Internet } \\
\text { cloud storages, accumulation and analysis } \\
\text { of vast amounts of information and solution } \\
\text { of complex problems through their } \\
\text { distribution between other "clouds" or } \\
\text { people all over the world to resolve them }\end{array}$ & $\begin{array}{l}\text { - exposure of tens of millions of } \\
\text { people to solving problems and } \\
\text { generating new knowledge } \\
\text { possibility; } \\
\text { - unlimited space for data storage; } \\
\text { - ability to access knowledge of a } \\
\text { certain circle of people from } \\
\text { anywhere at any time }\end{array}$ & $\begin{array}{l}\text { - the risks of knowledge getting } \\
\text { outside the enterprise; } \\
\text { - lack of control over the "shadow" } \\
\text { movement of knowledge; } \\
\text { - distrust to this technology }\end{array}$ \\
\hline $\begin{array}{l}\text { The collective } \\
\text { retention of } \\
\text { organizational } \\
\text { knowledge }\end{array}$ & $\begin{array}{l}\text { Main carriers of knowledge are the } \\
\text { concrete specialists }\end{array}$ & $\begin{array}{l}\text { - continuous knowledge exchange } \\
\text { between specialists; } \\
\text { - unambiguous interpretation; } \\
\text { - comprehensive explanation and } \\
\text { training }\end{array}$ & $\begin{array}{l}\text { - disappearance of knowledge with } \\
\text { the dismissal of employees; } \\
\text { - subjective assessment of the true } \\
\text { scope of a specialist's knowledge }\end{array}$ \\
\hline $\begin{array}{l}\text { Knowledge } \\
\text { mapping } \\
\text { (knowledge map) }\end{array}$ & $\begin{array}{l}\text { Method to show the location of the } \\
\text { knowledge (ideas) that are found in the } \\
\text { audit process }\end{array}$ & $\begin{array}{l}\text { - knowledge structuring; } \\
\text { graphical representation of the } \\
\text { relationships }\end{array}$ & $\begin{array}{l}\text { - for different people and different } \\
\text { knowledge views various maps of } \\
\text { knowledge are formed; } \\
\text { - there is no single way of preparation }\end{array}$ \\
\hline $\begin{array}{l}\text { Document } \\
\text { management } \\
\text { system }\end{array}$ & $\begin{array}{l}\text { Storage system of various documents, files } \\
\text { and images, including records, documents, } \\
\text { processing and spreadsheets programs and } \\
\text { others. }\end{array}$ & $\begin{array}{l}\text { - quick response to changes; } \\
\text { dynamic system; } \\
\text { - coverage of primary data and } \\
\text { their classification }\end{array}$ & $\begin{array}{l}\text { - narrow focus; } \\
\text { - uncomfortable to use (a great } \\
\text { number of documents) }\end{array}$ \\
\hline $\begin{array}{l}\text { The knowledge } \\
\text { base }\end{array}$ & $\begin{array}{l}\text { Database designed for knowledge manage- } \\
\text { ment, that is collection, storage, search and } \\
\text { delivery of knowledge for satisfying the } \\
\text { information needs of consumers }\end{array}$ & $\begin{array}{l}\text { - the possibility of self-learning and } \\
\text { self-correction } \\
\text { - new knowledge generating; } \\
\text { - focusing on the preservation and } \\
\text { creation of new knowledge }\end{array}$ & $\begin{array}{l}\text { - the need for highly qualified } \\
\text { specialists due to the use of pointed } \\
\text { system; } \\
\text { - narrow specialization }\end{array}$ \\
\hline System expert & $\begin{array}{l}\text { Expert systems are a research vector in the } \\
\text { field of artificial intelligence for creation of } \\
\text { computational systems, which are able to } \\
\text { make decisions, identical with the decisions } \\
\text { of experts in a given subject area. The expert } \\
\text { system is the result of joint work of experts, } \\
\text { engineers in the field of knowledge and } \\
\text { programmers }\end{array}$ & $\begin{array}{l}\text { - new knowledge generation; } \\
\text { - focusing on active use; } \\
\text { - search and development of new } \\
\text { solutions; } \\
\text { - a combination of not only } \\
\text { explicit, but also implicit elements; } \\
\text { - the opportunity to gain } \\
\text { knowledge in a narrow subject area }\end{array}$ & $\begin{array}{l}\text { - the need for specialized services; } \\
\text { - it is important that the experts } \\
\text { input data were well-chosen and } \\
\text { entered into the system; } \\
\text { - self-learning failure; } \\
\text { - failure to provide meaningful } \\
\text { explanations of their reasoning }\end{array}$ \\
\hline
\end{tabular}

Table 5

Corporate information portal implementation at the platform of modern software products

\begin{tabular}{|c|c|}
\hline Software product & Software product description \\
\hline $\begin{array}{l}\text { Microsoft Office } \\
\text { SharePoint }\end{array}$ & $\begin{array}{l}\text { Tight integration with MS Office and MS Exchange. This system is used as corporate portal. SharePoint improves team } \\
\text { performance through a dynamic and productive team sites for each project team, division or unit }\end{array}$ \\
\hline $\begin{array}{l}\text { IBM WebSphere } \\
\text { Portal }\end{array}$ & $\begin{array}{l}\text { Is an enterprise portal solution, business mashups and SOA Platforms. Creates redundant functionality for content } \\
\text { management at the enterprise }\end{array}$ \\
\hline $\begin{array}{l}\text { Oracle } \\
\text { WebCenter Suite }\end{array}$ & $\begin{array}{l}\text { Portal management platform for content and components to build portals for collaboration within key business processes, } \\
\text { integration of business data and applications }\end{array}$ \\
\hline $\begin{array}{l}\text { 1C-Bitrix: } \\
\text { Corporate portal }\end{array}$ & $\begin{array}{l}\text { Corporate portal solution (internal website). Offers all the necessary features for convenient storage and document storage } \\
\text { management. Provides the ability to conduct training courses. Integration with Microsoft Office and "1C: Salary and } \\
\text { Personnel Management" }\end{array}$ \\
\hline WebEx Connect & $\begin{array}{l}\text { SaaS system for communication and collaboration. Allows creating workspaces with document storage, calendar (integrated } \\
\text { with Outlook), forum, wiki, bookmarks, RSS. Built-in instant messenger and web conferences. Allows one to create business } \\
\text { mash-ups and corporate portals }\end{array}$ \\
\hline $\begin{array}{l}\text { SAP NetWeaver } \\
\text { Portal }\end{array}$ & $\begin{array}{l}\text { Portal platform for knowledge management, including Content Management system and classification system, Search \& } \\
\text { Classification (TREX). Structured document library with the possibility of personalized access and collaboration. Creation of } \\
\text { virtual rooms for collaboration of distributed user groups. The automation of some business processes. The portal supports both } \\
\text { J2EE and .NET }\end{array}$ \\
\hline RedDot CMS & $\begin{array}{l}\text { Portal solution for corporate communications, integration of IT infrastructure and enterprise content management. } \\
\text { Different interactive interface }\end{array}$ \\
\hline Drupal & $\begin{array}{l}\text { The most popular CMS system to control the operation of informational web portals. Multi-functional, provided by the } \\
\text { extension library, the system of joint publications, Open ID and has got high safety }\end{array}$ \\
\hline $\begin{array}{l}\text { Salesforce } \\
\text { Content }\end{array}$ & $\begin{array}{l}\text { The SaaS for content management integrates with Salesforce CRM Content. It is formed taking into account social tools, } \\
\text { in particular a tag, RSS subscriptions, recommendations and ratings. Intended for interaction both within the company, as } \\
\text { well as with customers and partners }\end{array}$ \\
\hline PayDox & $\begin{array}{l}\text { Corporate portal of the Smart Enterprise Suite level. Electronic document flow management system with functions for the } \\
\text { corporate portal. One of the functional features of the system is customer relationship management. Well integrated with } \\
\text { MS Office }\end{array}$ \\
\hline
\end{tabular}


changes in corporate culture should be aimed at building trust relations. In a practical sense, the multilevel model of trust building as a tool for knowledge exchange at XEROX-Poland1 deserves attention, which consists in the gradual "ascent" of staff from lower levels to higher ones.

The main link in the system of enterprise knowledge management, the dominant feature on the new quality of work creative, with high technological complexity and more intelligently organized, are human resources. Therefore, one of the main objectives of the enterprise knowledge management system is creation of the information environment, which should provide conditions for professional training and competency development, quick learning for new staff, skills support and development, the generation of new knowledge and its adequate application. We believe that training in business projects, teams work with development of innovative product methodology are crucial determinants of intrinsic employee motivation, which create intellectual capital of the enterprise. Thus, the knowledge management system will allow the distribution within an enterprise as the knowledge of individual employees and groups of employees (departments) and enterprise in general. To achieve the goal of the enterprise's accelerated evolutionary development to become an intelligent self-learning organization, we propose to develop a strategy of the employee's priority competences development. The most important component of this strategy is formation of new categories of specialists - the interdisciplinary "knowledge coordinators" who are responsible not only for knowledge management, but for creation of learning regulations and knowledge sharing procedures. An equally important task is creation of training programs which enable employees to understand the company's development strategy and requirements for new competencies, showing up, thus, as effective means of staff self-improvement. Compliance of these conditions will provide a conceptually new level of development for the enterprise. Firstly, knowledge bases are getting created, which are focused on priority activity vectors, which "are shaped" for future leadership. Secondly, the relation to products created at the enterprise is getting changed: new development suggests not only a product that is sold (the final stage of production), but also patents databases source replenishment and knowhow - the guarantee of future innovation.

Basing on the author's approach, the knowledge management system of an industrial enterprise is a formation, development and effective intellectual potential use process based on the enterprise's human factor, corporate culture and information technology integration for the goal of enterprise value increasing or creation and fundamentally new competitive advantages achieving.

The effectiveness of innovative products requires the use of specific methodological tools of the knowledge management, which determines industrial enterprises' conscious choice of the formats of their work and helps to regulate knowledge management organizational procedures to reformatting knowledge into a strategic asset of the enterprise. In order to identify the methods and tools of the enterprises' knowledge management system, we propose to group them within the components of this system (Table 6).

The effective functioning of the knowledge management system ensures continuous interaction of such subsystems as: knowledge acquisition, knowledge production, staff knowledge commercialization. Table 7 presents the tasks of knowl-

Table 6

Methodical tools of the knowledge management system $[9,11]$

\begin{tabular}{|c|c|}
\hline Knowledge management components & Methods and tools of knowledge management \\
\hline \multirow[t]{3}{*}{ Corporate structure and procedures } & Functional organized structural units of knowledge management \\
\hline & Project-oriented organizational structure \\
\hline & Institutionalization of knowledge management roles and functions \\
\hline \multirow[t]{8}{*}{ Information infrastructure } & Formalization of knowledge management data models \\
\hline & Platform and corporate portals of knowledge \\
\hline & The creation of a specialized organizational knowledge base \\
\hline & Enterprise content management system \\
\hline & $\begin{array}{l}\text { The map of knowledge due to the invention of intellectual assets being so important to the success of } \\
\text { the enterprise }\end{array}$ \\
\hline & Informational support in the context of interpersonal communication at professional and social levels \\
\hline & Discussion forums \\
\hline & Network system \\
\hline \multirow{7}{*}{$\begin{array}{l}\text { Values, norms, standards and rules, } \\
\text { which support corporate culture }\end{array}$} & Systematic meeting of the teams to exchange knowledge \\
\hline & Formation of proposals in the context of innovative solutions formalization regarding in-house training \\
\hline & Stimulation of individual communication for the two-way exchange of knowledge \\
\hline & Implementation of internal and external communication standards \\
\hline & New managerial decisions on the projects implementation platform \\
\hline & Promoting informal contacts, using team events \\
\hline & Exchange of professional information and experience of the highest rank managers and staff \\
\hline \multirow{7}{*}{$\begin{array}{l}\text { Intellectualization of human } \\
\text { resources }\end{array}$} & Measurement of corporate success by criterion of creating new and unique intellectual resources \\
\hline & Planning the employees' business career \\
\hline & $\begin{array}{l}\text { The development of professional education aimed at the dissemination of implicit knowledge, } \\
\text { coaching knowledge }\end{array}$ \\
\hline & $\begin{array}{l}\text { System of assessment and motivation, stimulating every employee to achieve internships and trainings } \\
\text { high results and continuous professional development }\end{array}$ \\
\hline & The motivation for successful knowledge sharing, in particular, implicit ones \\
\hline & Policy of labor and employees rotation structuring, focused on personality \\
\hline & Team spirit and teamwork skills development \\
\hline
\end{tabular}


Tasks of R\&D and innovations marketing at the stages of innovational cycle [4]

\begin{tabular}{|c|c|c|}
\hline $\begin{array}{l}\text { Stages of } \\
\text { innovational cycle }\end{array}$ & $\mathrm{R} \& \mathrm{D}$ & Marketing innovation \\
\hline $\begin{array}{l}\text { Generating ideas and } \\
\text { new product } \\
\text { development concept }\end{array}$ & $\begin{array}{l}\text { Application of ideas generating methods, such as: } \\
\text { analysis of the prototype, brainstorming, synectics, } \\
\text { "the deadlocked" situations elimination, } \\
\text { morphological maps and others. Forecasting technical } \\
\text { and economic indicators of product innovations }\end{array}$ & $\begin{array}{l}\text { The analyzing of customers' and other market entities' } \\
\text { current and future needs. Conformity assessment of new } \\
\text { products according to the market subjects requirements. } \\
\text { New directions of market attractiveness, product innovations }\end{array}$ \\
\hline Business analysis & $\begin{array}{l}\text { Technical and economic characteristics of product } \\
\text { innovation specification. The formation of the } \\
\text { business idea, the main goals and objectives of the } \\
\text { innovation project }\end{array}$ & $\begin{array}{l}\text { Conducting a complex of marketing research studies of } \\
\text { strategy development and marketing programs to promote } \\
\text { the new product in the market. Evaluation of marketing } \\
\text { potential of an enterprise }\end{array}$ \\
\hline $\begin{array}{l}\text { The development of } \\
\text { a new product }\end{array}$ & $\begin{array}{l}\text { Development of the design and the process } \\
\text { documentation, testing the technology, pre-test } \\
\text { prototype, state tests (if necessary) }\end{array}$ & $\begin{array}{l}\text { Refining the target market, assessing the competitive } \\
\text { position of the product innovation, the development of } \\
\text { market testing program }\end{array}$ \\
\hline Market testing & $\begin{array}{l}\text { Adjustment of design product innovation and } \\
\text { technology of its manufacturing according to the } \\
\text { results of the market test }\end{array}$ & Method of test marketing \\
\hline $\begin{array}{l}\text { Outputting innovation } \\
\text { into the market }\end{array}$ & $\begin{array}{l}\text { A comprehensive set of studies upon the development } \\
\text { of new products and its manufacturing technology }\end{array}$ & $\begin{array}{l}\text { Implementation of innovations marketing complex } \\
\text { measures. Analysis of the market adequacy of new products, } \\
\text { marketing situation }\end{array}$ \\
\hline
\end{tabular}

edge production subsystem components at the stages of the innovation cycle. At the same time, the priority areas of enterprise knowledge production and commercialization are determined on the basis of industry trends in science and technology development forecasting, as well as changes in the external micro and macro environment, and, as a consequence, changes in consumer demand.

Conclusions. The strategic direction of industrial enterprises' innovation development is the effective use of intellectual potential on the basis of the human factor and information technologies, improvement of the enterprise's organizational knowledge management [12]. Consequently, basing on the principles of quality management we have built a knowledge management system that provides the possibility of achieving the enterprise's strategic goals of development. Given the above, the introduction of a system of knowledge management provides the enterprise with a number of advantages, which include the following: providing information and communication environment of the enterprise; involvement of the employees of all levels into the knowledge management process; improving the relationship of employees as a result of active information exchange, ideas sharing in the innovation process; reducing the development cycle of the decision-making process new products and improvement based on the use of general knowledge and experience; improving cooperation and partnerships for the promotion of information from consumers flowing through the feedback channels; rather, the response of enterprises to changes in market demands due to the use of common knowledge; the formation of the proper skills and mindset of the enterprise personnel at all levels through structured programs of teaching and learning to staff and enhance their awareness; ensuring motivation of employees to increase the level of labor intellectualization; the effective use and appreciation of the enterprise intellectual potential; the restructuring of the internal corporate control vector of more active knowledge use that improves the management efficiency and enterprise competitiveness. Thus, it seems quite logical that at modern enterprises the implementation, maintenance and development of the knowledge management system, the main vector of which is the intellectual resources activation, creates a solid foundation for creating a company's strategic intangible assets (specific, unique, rare knowledge), which is a key success factor in the competitive struggle in conditions of economy knowledge-based formation. As a result of knowledge management introduction in the enterprise, added value is obtained through creation of new competitive products which are able to satisfy the growing needs of consumers.

\section{References.}

1. Pylypenko, H., Fedorova, N., Kuzenko, I., \& Naumenko, N. (2020). Paradoxes of economic development: science and innovation in the modern world. Naukovyi Visnyk Natsionalnoho Hirnychoho Universytetu, (2), 153-159. https://doi. org/10.33271/nvngu/2020-2/153.

2. Wiig, K. (n.d.). Knowledge Management Foundations: Thinking About Thinking: How People and Organizations Create, Represent and Use Knowledge. Retrieved from https://www.academia.edu/19382981/.

3. Martynenko, M., \& Menshykov, O. (2015). Development of organisational knowledge system in the structure of vocational education. Economics and management of national economy. Retrieved from http://soskin.info/en/ea/2017/165-5-6/Economic-Annals-contents-V165-14.

4. Illiashenko, S. M., Shypulina, Yu. S., Illiashenko, N. S., \& Nahornyi, Ye. I. (2018). Knowledge management in the context of raising the level of potential of the organization >s innovative development. Bulletin of Khmelnytskyi National University. Economic sciences, 3(2), 98-103.

5. Smolinska, N., \& Hrybyk, I. (2015). Knowledge management as a tool for providing innovative devel-opment of the enterprise. Bulletin of the National University "Lviv Polytechnic”, 815, 248-255.

6. Sytnyk, Y. S. (2017). Intellectualization of enterprise management systems: concept, system monitoring and modeling: monograph. Lviv: Lviv Polytechnic Publishing House.

7. Nalyvayko, A. (Ed.) (2014). Strategic management of knowledge of the enterprise. Monograph. Kyiv: KNEU.

8. Knowledge management is the challenge of the future (n.d.). Retrieved from http://www.management.com.ua/hrm/hrm016. html.

9. Ostrovska, H. Y. (2019). Knowledge management system as an instrument for efficient use of intellectual potential of the enterprise. Economic forum. Lutsk, (1), 104-110.

10. Fundamental Concepts of EFQM. European Foundation of Quality Management (n.d.). Retrieved from http://ww1.efam. org/en/Home/aboutEFQM/Ourmodels/FundamentalConcepts/tabid/169/Default.aspx.

11. Gallagher, S., \& Hazlett, S. (n.d.). Using the Knowledge Management Maturity Model (KMM). As An Evaluation Tool. Retrieved from http://bprc.warwick.ac.uk/km028.pdf. 
12. Ostrovska, H., Demianyshyn, V., Maliuta, L., Sherstiuk, R., Kuz, T., \& Reznik, N. (2020). View of Intellectual Potential of Ukraine: Realies and Prospects of Efficient Use in the Knowledge-Based Economy Conditions. International Journal of Advanced Science and Technology, 29(9s), 4622-4634.

\section{Розвиток інтелектуального потенціалу в системній парадигмі менеджменту знань}

\section{Г. Й. Островська ${ }^{1}$, Л.Я. Малюта 1 , Р. П. Шерстюк ${ }^{1}$, I. В. Луциків ${ }^{1}$, I. А. Ясінецька ${ }^{2}$}

1 - Тернопільський національний технічний університет імені Івана Пулюя, м. Тернопіль, Україна, е-mail: h.ostrovska@gmail.com,

2 - Подільський державний аграрно-технічний університет, м. Кам’янець-Подільський, Україна

Мета. Поглиблення методологічного підгрунтя й розроблення рекомендацій щодо формування інтегрованої системи менеджменту знань як інструменту розвитку інтелектуального потенціалу промислових підприємств, на основі принципів управління якістю, задля досягнення головної стратегічної мети.

Методика. Методологічну основу менеджменту знань складають: теорії економіки знань, підприємництва, інституціоналізм, мікроекономічна теорія управління знаннями, теорії перетворення знань, отримання нових знань, концепція самонавчальної організації, концепція «потрійної спіралі». Основою застосування методології є системний аналіз як науковий метод дослідження функцій менеджменту знань організацій.

Результати. Здійснене теоретичне та прикладне узагальнення становлення концепції менеджменту знань промислових підприємств в умовах економіки, заснованої на знаннях. Запропоноване нове розуміння сутності категорій «менеджмент знань промислового підприємства» й «система менеджменту знань промислового підприємства». Обгрунтоване впровадження системи менеджменту знань, що забезпечує вдосконалення процесів акумулювання, інтеграції знань у поле діяльності підприємства та обміну знаннями між співробітниками та ключовими стейкхолдерами. Розроблені рекомендації щодо вдосконалення менеджменту знань на промислових підприємствах, а також запропоновані механізми їх практичної реалізації.

Наукова новизна. Удосконалена методологія управління підприємством як динамічною системою на основі менеджменту знань. Розроблена концепція розвитку цілісної системи менеджменту знань і методичне забезпечення іiі ефективного застосування. Запропонована інтегративна модель системи менеджменту знань підприємства у руслі процесного підходу відображає практичні аспекти концепції менеджменту знань і засновується на принципах управління якістю 3 метою трансформації підприємства у самонавчальну організацію. Реалізація даної концепції дає змогу створити для кожного підприємства життєздатну, ефективну керуючу систему, що забезпечує перманентну результативність формування та реалізації процесів навчання в усіх структурних підрозділах і в усіх формах.

Практична значимість. Запропоновані розробки й рекомендації авторів можуть бути використані в контексті підвищення ефективності управління інтелектуальним потенціалом задля збільшення економічної доданої вартості за рахунок генерування організаційних знань.

Ключові слова: інтелектуальний потенціал, менеджмент знань, система менеджменту знань, промислове підприємство, людські ресурси, корпоративна культура, інформаційна інфраструктура

\section{Развитие интеллектуального потенциала в системной парадигме менеджмента знаний}

\author{
Г. И. Островская ${ }^{1}$, Л. Я. Малюта ${ }^{1}$, Р. П. Шерстюк ${ }^{1}$, \\ И. В. Луцикив ${ }^{1}$ И. А. Ясинецкая ${ }^{2}$
}

1 - Тернопольский национальный технический университет имени Ивана Пулюя, г. Тернополь, Украина, e-mail:h.ostrovska@gmail.com

2 - Подольский государственный аграрно-технический университет, г. Каменец-Подольский, Украина

Цель. Углубление методологической основы и разработка рекомендаций по формированию интегрированной системы менеджмента знаний как инструмента развития интеллектуального потенциала промышленных предприятий на основе принципов менеджмента качества для достижения главной стратегической цели.

Методика. Методологическую основу менеджмента знаний составляют: теории экономики знаний, предпринимательства, институционализм, микроэкономическая теория управления знаниями, теории преобразования знаний, получения новых знаний, концепция самообучающейся организации, концепция «тройной спирали». Основой применения методологии является системный анализ как научный метод исследования функций менеджмента знаний организаций.

Результаты. Осуществлено теоретическое и прикладное обобщение становления концепции менеджмента знаний промышленных предприятий в условиях экономики, основанной на знаниях. Предложено новое понимание сущности категорий «менеджмент знаний промышленного предприятия» и «система менеджмента знаний промышленного предприятия». Обоснованно внедрение системы менеджмента знаний, что обеспечивает совершенствование процессов аккумулирования, интеграции знаний в поле деятельности предприятия и обмена знаниями между сотрудниками и ключевыми стейкхолдерами. Разработаны рекомендации по совершенствованию процессов менеджмента знаний на промышленных предприятиях, а также предложены механизмы их практической реализации.

Научная новизна. Усовершенствована методология управления предприятием как динамической системой на основе менеджмента знаний. Разработана концепция развития целостной системы менеджмента знаний и методическое обеспечение ее эффективного применения. Предложенная интегративная модель системы менеджмента знаний предприятия, в русле процессного подхода, отражает практические аспекты концепции менеджмента знаний и основывается на принципах управления качеством с целью трансформации предприятия в самообучающуюся организацию. Реализация данной концепции позволяет создать для каждого предприятия жизнеспособную, эффективную управляющую систему, обеспечивающую перманентную результативность формирования и реализации процессов обучения во всех структурных подразделениях и во всех формах.

Практическая значимость. Предложенные разработки и рекомендации авторов могут быть использованы в контексте повышения эффективности управления интеллектуальным потенциалом для увеличения экономической добавленной стоимости за счет генерирования организационных знаний.

Ключевые слова: интеллектуальный потенциал, менеджмент знаний, система менеджмента знаний, промышленное предприятие, человеческие ресурсы, корпоративная культура, информационная инфраструктура

Recommended for publication by B. M. Andrushkiv, Doctor of Economic Sciences. The manuscript was submitted 08.12.19. 